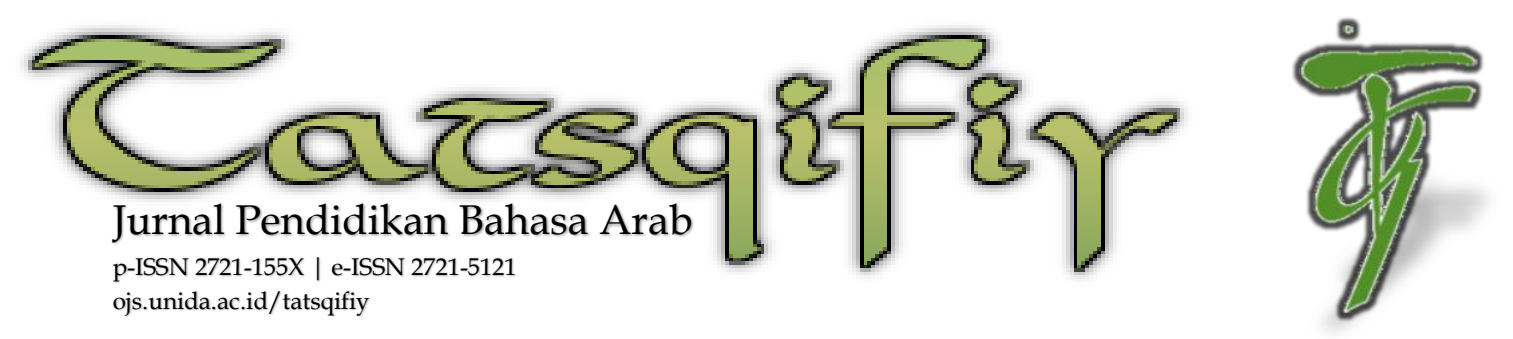

\title{
Pembelajaran Bahasa Arab melalui Teknik Flashcard untuk Meningkatkan Kosakata Siswa Kelas VII MTs Al-Muchtari Cimande
}

\author{
Silma Anjani, Radif Khotami Rusli, Tb. Bay Amri Hakim \\ Pendidikan Bahasa Arab, Fakultas Keguruan Dan Ilmu Pendidikan \\ Universitas Djuanda Bogor \\ Jl. Tol Ciawi 1 Kotak Pos 35 Bogor 16720
}

Volume 2 Nomor 1

Januari 2021: 45-60

DOI: $10.30997 /$ tjpba.v2i1.3623

Article History

Submission: 10-10-2020

Revised: 25-11-2020

Accepted: 01-01-2021

Published: 25-01-2021

Kata Kunci:

Pembelajaran Bahasa Arab, Kosakata, Flashcard

$\underline{\text { Keywords: }}$

Learning Arabic language, Vocabulary, Flashcard

Korespondensi:

(Silma Anjani)

(082124055578)

(anjanisilma@gmail.com)
Abstrak: Penelitian ini mempunyai tujuan untuk mendeskripsikan pentingnya pembelajaran dalam peningkatan penguasaan pada kosakata bahasa Arab menggunakan teknik flashcard. Metode yang dipakai dalam penelitian ini adalah metode kuantitatif dan jenis penelitian ini adalah eksperimen dengan menggunakan desain posttest only. Data yang dikumpulkan memakai teknik observasi, dokumentasi, serta soal posttest. Hasil akhir penelitian ini disimpulkan bahwa pada uji normalitas hasil posttest peningkatan kemampuan kosakata bahasa Arab berdistribusi normal. Sesudah diketahui bahwa tingkat kenormalan data, selanjutnya adalah dilaksanakan uji homogenitas. Hasil post-test peningkatan penguasaan kosakata bahasa Arab siswa dapat disimpulkan bahwa varian kelas eksperimen dan kelas kontrol homogen. Dan yang terakhir adalah penilaian hasil analisis uji-t terhadap meningkatnya penguasaan kosakata siswa dapat diartikan bahwa $\mathrm{Ha}$ diterima karena terdapat peningkatan penguasaan kosakata dengan memakai pembelajaran bahasa Arab lewat teknik flashcard. Maka dapat dinyatakan bahwa data hasil posttest berdistribusi normal dan hasil posttest bisa disimpulkan dengan memakai teknik flashcard pada pembelajaran bahasa arab dapat menaikkan kemampuan kosakata siswa dan siswi kelas VII MTs Al-Muchtari Cimande-Bogor. The Arabic Learning Model Through Flashcard Techniques For The Vocabulary Mastery Improvement In Class VII MTs Al-Muchtari Cimande

Abstract: This study aims to describe the importance of learning in increasing mastery of Arabic vocabulary using the flashcard technique. The method used in this study is a 
quantitative method and this type of research is an experiment using a posttest only design. Data collected using observation techniques, documentation, and posttest questions. The final results of this study concluded that the normality test of the post-test results of the increase in the ability of Arabic vocabulary is normally distributed. After it is known that the level of normality of the data, then the homogeneity test is carried out. The results of the post-test on the increase in students' Arabic vocabulary mastery can be concluded that the variants of the experimental class and the control class are homogeneous. And the last one is the assessment of the results of the t-test analysis of the increase in students' vocabulary mastery, it can be interpreted that $\mathrm{Ha}$ is accepted because there is an increase in vocabulary mastery by using Arabic learning through the flashcard technique. So it can be stated that the post-test result data is normally distributed and the post-test results can be concluded by using the flashcard technique in learning Arabic to increase the vocabulary skills of students and class VII students of MTs Al-Muchtari Cimande-Bogor.

\section{PENDAHULUAN}

Ilmu bahasa Arab terlahir dan berkembang dalam kitab suci AlQur'an. Kedudukan yang istimewa dipunyai bahasa Arab diantara bahasabahasa dunia lainnya adalah karena berfungsi sebagai Al-Qur'an, hadits, dan kitab-kitab lainnya, serta bahasa Arab dipakai sebagai bahasa Al-Qur'an dgn jelasnya tidak adanya kesalahan sedikitpun.

Khususnya bahasa Arab penyebarannya yang telah banyak dilihat di beberapa daerah atau negara. Proses sebaran bahasa Arab di berbagai negara adalah pengaruh dari perkembangan agama dan ajaran islam dimana ajaran agama islam bersumber pada (Al-Qur'an dan as-sunah) yang memakai bahasa Arab.

Mempelajari bahasa Arab beda halnya dengan belajar bahasa ibu yang memerlukan usaha dan bukan ditempuh dalam waktu yang singkat. Oleh sebab itu prinsip awal pengajarannya harus berbeda, baik dari metode (model pembelajaran), materi maupun pelaksanaan pembelajarannya. Pembelajaran bahasa mengutamakan beberapa keterampilan yaitu (listening competence/mahaarah al-istima'), (speaking competence/mahaarah al-takallum), (reading competence/ma-haarah al qira'ah), dan (writing competence/mahaarah al kitaabah). 
Keterampilan bahasa erat sangat hubungannya dengan semua proses yang mengawali perolehan bahasa seseorang, karena bahasa adalah cerminan untuk pola berpikir seseorang maka hendaknya harus menguasai keterampilan-keterampilan tersebut secara baik (Nuha, 2012). Walaupun untuk menguasai keempat keterampilan berbahasa itu sulit, tetapi bukan suatu yang mustahil untuk bisa menguasai ke empat keterampilan berbahasa tersebut.

Setiap tantangan pasti memiliki prospek dan peluang masa depan. Akan tetapi ketika tantangan tersebut dihadapi dengan penuh keyakinan, kesungguhan, kearifan dan tentu dengan pemikiran yang positif maka akan menghasilkan prospek ke depan yang baik dan positif. Hal ini yang sedang dihadapi bahasa Arab, yaitu apa prospek dan peluang yang nantinya diperoleh oleh seseorang belajar bahasa Arab. Prospek dan peluang belajar bahasa Arab di masa yang akan datang dapat diraih jika para siswa yang belajar bahasa Arab menekuninya dengan berusaha merubah tantangan menjadi peluang. Namun permasalahan yang ada yaitu sejauh mana para guru bahasa
Arab mengembangkan sistem pengajarannya agar siswa termotivasi untuk pelajari bahasa Arab.

Terlebih khusus didalam dunia pendidikan manusia wajib menimba ilmu karena lewat pendidikan manusia bisa meningkatkan watak dan dinaikkan derajatnya, seperti di firman Allah SWT pada Q.S Al-Mujadilah:11

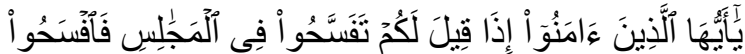

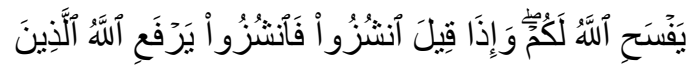

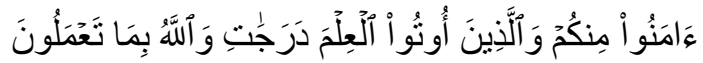
خَبيرً

Artinya : "Wahai orang-orang yang beriman, apabila dikatakan kepadamu berilah kelapangan di dalam majelis-majelis, maka lapangkanlah untukmu. Dan apabila dikatakan,'berdirilah kamu' maka berdirilah, niscaya Allah akan mengangkat (derajat) orang-orang yang beriman di antaramu dan orang-orang yang diberi ilmu beberapa derajat. Dan Allah maha mengetahui terhadap apa yang kamu kerjakan." (Q.S AlMujadilah: 11)

Di surah Al-Mujadilah ayat 11 ini bermakna bahwa manusia yang diangkat derajatnya di sisi Allah SWT adalah manusia yang beriman, bertakwa dan mengerjakan amal soleh serta berilmu pengetahuan. Jika seseorang berilmu pengetahuan dan 
telah menguasai dan mendalami kosakata bahasa Arab, maka dengan mudah mendapatkan akses kerjasama dengan pihak asing terutama negara timur tengah, serta terampil dalam penggunaan iptek dan mampu melahirkan inovasi-inovasi baru dalam bidang pengajaran bahasa Arab.

Walau bahasa Arab adalah salah satu bagian utama dari tradisi islam, tapi tetap saja kesulitan dalam belajar bahasa Arab. Begitu pula dengan pesanpesan di ayat Al-Qur'an senantiasa memberikan isyarat seperti apa bahasa Arab jadi sebuah alat yang paralel dengan keberadaan Al-Qur'an itu sendiri. Inovasi pembelajaran seiring dengan kesulitan itu juga tumbuh untuk menjawab tantangan problematika tersebut (Wekke, 2016).

MTs

$$
\text { Al-Muchtari }
$$

Cimande merupakan sekolah madrasah tsanawiyah berdiri dan berlandaskan Islam yang berlokasi di Jl. Raya Sukabumi KM.15 HE. Sukma Talang 2 Cimande, Caringin-Bogor. Menurut pantauan peneliti saat melakukan observasi ada beberapa faktor yang mengakibatkan kurangnya penguasaan kosakata dan minat belajar bahasa Arab yakni 30\% siswa menghadapi kesulitan menghafal kosakata bahasa Arab sebab guru tidak memiliki keterampilan untuk melatih siswa menguasai pelajaran bahasa Arab, walaupun beberapa siswa terlihat aktif dalam proses belajar. Padahal kosakata menjadi bagian yang perlu untuk menopang aktivitas belajar bahasa, kurangnya inovasi dan motivasi guru mata pelajaran tersebut sehingga menimbulkan kejenuhan terhadap siswa, efektivitas model belajar yang kurang variatif sehingga pembelajaran sering disampaikan secara lisan saja tanpa ada model belajar pendukung yang bisa mendorong minat siswa saat guru menjelaskan materi, serta guru mengajar dengan cara kurang kompeten sehingga mengakibatkan kebosanan siswa karena tidak terlibat secara penuh, metode ceramah, tanya jawab masih sering digunakan ketika menjelaskan materi belajar hingga siswa cepat merasa jenuh.

Salah satu bentuk inovasi yang dapat peneliti lakukan untuk meningkatkan pemahaman kosakata siswa yaitu menggunakan model pembelajaran, sebab kebaikan ataupun keburukan dalam sebuah model belajar sangat bergantung terhadap 
kemampuan guru dalam mengoperasionalkan model tersebut.

Bahasa Arab adalah salah satu pelajaran yang memerlukan kemampuan guru mengelola kelas hingga bisa menarik minat dan mengaktifkan siswa untuk ikuti pembelajaran. Kehadiran model pelajaran adalah sangat punya arti dan makna yang penting diproses belajar dan mengajar, karena di kegiatan tersebut ketidakterangan bahan dan teknik yang disampaikan bisa dibantukan melalui model pembelajaran. Model belajar yang bisa dipakai guru dalam meningkatkan penguasaan kosakata bahasa Arab untuk siswa dengan memakai teknik flashcard yang diterapkan dengan bentuk permainan. Aktivitas permainan dapat dilakukan untuk menghindari kesulitan-kesulitan yang dihadapi oleh siswa, serta belajar dan bermain dalam pembelajaran bahasa Arab sangat penting, yang hal ini merupakan bagian dari aktivitas atau cara untuk menciptakan metode kreatif yang memudahkan siswa dalam memahami dan menyerap pengetahuan kosakata bahasa Arab.
Berdasarkan permasalahan yang peneliti uraikan diatas maka Madrasah Tsanawiyah Al-Muchtari merasa perlu menggunakan model flashcard dalam pembelajaran bahasa Arab pada siswa. Dalam rangka menaikkan penguasaan kosakata bahasa Arab kelas VII di MTs Al-Muchtari Cimande. Dengan harapan peneliti dapat memberikan solusi dalam pengembangan pendidikan dan keilmuan untuk membangun motivasi belajar peserta didik khususnya pada bidang pendidikan bahasa Arab lebih baik dan meningkat lagi.

Flashcard sendiri adalah alat peraga untuk memberikan kemudahan kepada siswa dengan cepat memahami pelajaran bahasa Arab, tinjauan peneliti terhadap MTs Al-Muchtari kurangnya minat serta pemahaman siswa terhadap pelajaran bahasa Arab, oleh sebab itu peneliti ingin mewujudkan teknik flashcard untuk meningkatkan penguasaan kosakata kelas VII, sebab alat peraga sangat berkesinambungan dengan permainan bahasa dan hal ini bisa dikatakan kartu pengingat yang diperlihatkan sekilas pada siswa untuk memahami kosakata bahasa Arab dan pembelajaran tidak membosankan. 
Flashcard biasanya berukuran $8 \times 12$ cm, atau dapat disesuaikan dengan besar kecilnya kelas yang dihadapi (Arsyad, 2016). Kartu yang punyai isi (benda-benda, binatang, dan sebagainya bisa dipakai untuk meningkatkan kosakata sebab kartu-kartu itu jadi petunjuk dan rangsangan kepada siswa untuk memberikan respon yang diinginkan.

Bermain sambil belajar bahasa Arab, diibaratkan siswa madrasah tsanawiyah Al-Muchtari seperti anak kecil yang sedang belajar bahasa pertamanya yang mana selalu mengulang sesuatu. Dalam tahap meningkatkan kosakata bahasa Arab, siswa sangat perlu mempraktikkan bahasa Arab sepanjang waktu bukan hanya saat pembelajaran saja akan tetapi saat keseharian pula. Serta permainan bahasa tidak hanya dipahami secara teoritis, tetapi harus dirancang sedemikian rupa agar nanti tidak terjadi kekeliruan yang berakibat fatal. Peneliti menggabungkan teknik flashcard dengan permainan bahasa dengan tujuan supaya siswa lebih cepat menghafal dan meningkatkan pemahaman kosakata bahasa Arab dengan model pelajaran yang tak membosankan.

\section{METODE}

Penelitian ini menggunakan metode kuantitatif yang dapat diartikan sebagai metode penelitian yang berlandaskan pada filsafat positivisme, digunakan untuk meneliti pada populasi tertentu, teknik pengambilan sampel pada umumnya dilaksanakan secara random, pengumpulan data menggunakan instrumen penelitian, analisis data bersifat kuantitatif dengan tujuan untuk menguji hipotesa yang telah ditetapkan (Sugiyono, 2015).

Dalam rancangan ini hanya kelas eksperimen saja yang diberi perlakuan khusus yaitu penggunaan teknik flashcard, penelitian ini bermaksud untuk menyelidiki secara langsung sebab akibat dengan menggunakan dua kelompok variabel yaitu satu kelompok kontrol dan satu kelompok eksperimen agar memperbaiki serta meningkatkan tercapainya suatu pembelajaran serta guna untuk mengetahui penguasaan kosakata bahasa Arab terhadap peserta didik kelas VII MTs Al-Muchtari Cimande-Bogor.

Desain penelitian merupakan suatu rencana tentang cara mengumpulkan, mengolah dan menganalisis data secara sistematis dan terarah agar penelitian 
dapat dilaksanakan secara efisien dan efektif sesuai tujuannya. Desain penelitian adalah pedoman bagi seorang peneliti dalam melaksanakan penelitian agar data dapat dikumpulkan secara efisien dan efektif, serta dapat diolah dan dianalisis sesuai dengan tujuan yang ingin dicapai.

Desain penelitian ini adalah PosttestOnly Control yang berbentuk Quasi eksperiment, desain ini mempunyai 2 kelompok yaitu kelompok kontrol dan kelompok eksperimen. Untuk kelas eksperimen diberikan perlakuan menggunakan teknik flashcard sedangkan kelas kontrol hanya pemberian kosakata saja dan diakhir diberikan post-test berupa pengujian kosakata bahasa Arab.

Penelitian dilaksanakan pada semester genap tahun ajaran 2018/2019 bertempat di MTs Al-Muchtari di J1.Raya Sukabumi KM.15 HE.Sukma Talang 2 Cimande, Kec. Caringin- Kab. Bogor.

$$
\text { Populasi adalah wilayah }
$$
generalisasi yang terdiri atas subyek atau obyek serta karakteristik yang dimiliki oleh populasi tersebut. Populasi adalah wilayah generalisasi yang terdiri atas obyek/subyek yang mempunyai kualitas dan karakteristik tertentu yang ditetapkan oleh peneliti untuk dipelajari dan kemudian ditarik kesimpulannya (Sugiyono, 2015)

Sampel adalah wilayah jumlah karakteristik yang dimiliki oleh populasi tersebut (Sugiyono, 2012). Pengambilan sampel dilakukan memakai sampel tidak random. Sampel bertujuan ini didasari atas adanya tujuan tertentu kepada 31 siswa kelas VII MTs Al-Muchtari Cimande. Pengambilan sampel dilakukan memakai sampel tidak random. Sampel bertujuan ini didasari atas adanya tujuan tertentu kepada 31 siswa kelas VII MTs Al-Muchtari Cimande.

Peneliti membagikan kelompok kotrol dan eksperimen dengan dibagi dua kategori yaitu dengan siswa lakilaki dan siswi perempuan.

\begin{tabular}{lllll}
\multicolumn{5}{c}{ Tabel 1 sampel penelitian } \\
\hline Siswa & $\begin{array}{l}\text { Jumlah } \\
\text { Siswa }\end{array}$ & $\begin{array}{l}\text { Pre- } \\
\text { test }\end{array}$ & $\begin{array}{l}\text { Flashca } \\
\text { rd }\end{array}$ & $\begin{array}{l}\text { Post- } \\
\text { test }\end{array}$ \\
\hline Laki-Laki & 16 & Ya & Ya & Ya \\
\hline Perempuan & 15 & Ya & Tidak & Ya \\
\hline
\end{tabular}

Variabel penelitian pada dasarnya adalah segala sesuatu yang berbentuk apa saja yang ditetapkan oleh peneliti untuk dipelajari sehingga diperoleh informasi tentang hal tersebut, kemudian ditarik kesimpulannya. 
Penelitian ini akan menggunakan dua macam variabel penelitian yaitu variabel independen (variabel bebas) $\mathrm{X}$ yaitu teknik flashcard, dan variable dependen (variable terikat) $\mathrm{Y}$ yaitu penguasaan kosakata bahasa Arab.

Teknik pengumpulan data adalah langkah yang paling utama dalam penelitian, karena tujuan utama dari penelitian adalah mendapatkan data. Tanpa mengetahui teknik pengumpulan data, maka peneliti tak akan mendapatkan data yang memenuhi standar data yang ditetapkan pengumpulan data dapat dilakukan dalam berbagai pengaturan, berbagai sumber, berbagai data (Sugiyono, 2012). Teknik pengumpulan data berisi tentang langkah-langkah yang ditempuh peneliti untuk mendapatkan data. Penelitian model pembelajaran bahasa Arab melalui teknik flashcard untuk peningkatan penguasaan kosakata siswa kelas VII MTs AlMuchtari Cimande, maka teknik pengumpulan datanya adalah: a) Observasi adalah proses yang kompleks, suatu proses yang tersusun dari berbagai proses biologis dan psikologis. Dua diantaranya sangat penting dalam proses pengamatan dan ingatan (Sugiyono, 2012). Observasi adalah cara untuk mengadakan penilaian dengan jalan pengamatan secara langsung dan sistematis. Teknik ini bertujuan untuk mengumpulkan data antara lain: mengamati lembaga sekolah, serta proses belajar mengajar bahasa Arab. b) dokumentasi yaitu untuk mengumpulkan data dengan melihat atau mencatat langsung proses yang sedang diuji, metode ini dilakukan dengan melihat dokumen seperti gambar, catatan, dan monografi. c) Soal posttest adalah latihan tertulis yang dipakai untuk mengukur kognitif dan psikomotorik yang dimiliki siswa. Dan melihat pemahaman kosakata bahasa Arab yang dimiliki siswa setelah diterapkannya teknik flashcard. Serta peneliti akan mengetahui uji keberhasilannya.

Data merupakan penelitian inti karena guna untuk mendapakan hasil akhir dalam penelitian maka perlu diadanya instrumen penelitian. Uji instrumen dilakukan peneliti guna mengetahui kelayakan instrumen sebagai alat peneliti untuk digunakan pada sat posttest. Validitas adalah kemampuan soal bahasa mengukur kemampuan bahasa Arab siswa baik 
keterampilan bahasa maupun komponen bahasa. Validitas tes bahasa arab bisa dilakukan dengan melakukan penetapan tujuan dari tes bahasa Arab, membuat kisi - kisi, membuat soal, menela'ah soal, membuat kunci atau pedoman - pedoman penskoran, uji coba soal, perbaikan soal berdasar pada hasil uji coba (Matsna, 2014). Disamping itu ada beberapa faktor yang menentukan tingginya reliabilitas suatu tes yaitu dilihat dari instrumennya semakin banyak butir soal semakin menentukan tingkat reliabilitas, daya beda butir yang tinggi akan menentukan tingginya reliabilitas sebuah tes, menambah option, dan merevisi soal kembali (Matsna, 2014). Teknik analisis data adalah analisis dalam penelitian jenis apapun, merupakan cara berpikir (Sugiyono, 2012). Hal itu berkaitan dengan pengujian secara sistematis terhadap sesuatu untuk menentukan bagian, hubungan antar bsgian, hubungannya dengan keseluruhan, dan analisis adalah untuk mencari pola.

Peneliti menyimpulkan teknik analisis data merupakan suatu langkah yang paling menentukan dari suatu penelitian, karna analisis data berfungsi untuk menyimpulkan hasil.

Analisis deskriptif dengan pendekatan kuantitatif, yaitu analisis berupa statistik yang berfungsi untuk medeskripsikan/memberi gambaran terhadap objek yang diteliti melalui data populasi. Statistik deskriptif adalah statistik yang digunakan untuk menganalisis data dengan cara menggambarkan data yang telah terkumpul sebagaimana adanya tanpa bermaksud membuat kesimpulan yang berlaku untuk umum (Sugiyono, 2012).

Analisis deskriptif digunakan untuk menjelaskan minat dan peningkatan penguasaan kosakata siswa kelas VII MTs Al-Muctari Cimande, peneliti akan mendeskripsikan analisis deskriptif mengenai rata-rata. Peneliti akan membagi nilai rata-rata menjadi:

1) Mean digunakan untuk mencari nilai rata-rata dari skor total kekeliruaan jawaban yang diberikan oleh responden, yang tersusun dalam distribusi data.

2) Median digunakan untuk mencari nilai tengah dari skor total keseluruhan jawaban yang diberikan oleh responden, yang tersusun dalam distribusi data. 
3) Modus adalah nilai yang sering muncul disebut nilai yang frekuensinya banyak dalam distribusi data. Dalam penelitian ini modus digunakan untuk mencari jawaban yang sering muncul yang frekuensinya paling banyak dari responden dalam mengisi soal untuk mengetahui peningkatan penguasaan kosakata siswa kelas VII MTs Al-Muchtari.

Analisis varian merupakan proses aritmatika untuk membagi jumlah kuadrat total jadi beberapa komponen yang berhubungan dengan sumber keragaman yang diketahui. Model analisis varian digunakan untuk menganalisis pengaruh perubahan bebas terhadap perubahan tak bebas. Varian tebagi kedalam dua bagian yaitu varian sampel dan varian populasi (Hartati, 2017).

\section{HASIL \& PEMBAHASAN}

Dan melihat pemahaman kosakata bahasa Arab yang dimiliki siswa setelah diterapkannya teknik flashcard. Serta peneliti akan mengetahui uji keberhasilannya. Penelitian ini memiliki 3 siklus dari proses perlakuan hingga proses pengumpulan data, berikut ini peneliti akan mendeskripsikan hasil data penelitian: Uji Validitas

Sebelum peneliti memberikan soal post-test kepada siswa/i yang menjadi subjek penelitian atau sampel penelitian, peneliti terlebih dahulu melakukan validasi dengan cara memberikan soal kepada siswa/i kelas VII dari sekolah yang berbeda untuk mengetahui kevalidan soal tersebut. Tempat yang digunakan untuk validasi adalah di MTs Daarul Uluum Tahfidz Lido.

Setelah lakukan uji validitas pada siswa/i untuk menentukan valid atau tidaknya soal tersebut dengan cara siswa tersebut menjawab soal yang diberikan oleh peneliti. Dari hasil pengambilan data dan uji validity dengan bantuan SPSS 21.0, maka hasilnya yaitu jika $r$ hitung > (lebih besar dari) $r$ tabel soal tersebut dinyatakan valid. Dengan melihat tabel apabila peneliti mengambil responden sebanyak $20 \quad$ orang/siswa menggunakan a $=0.05$ maka $\mathrm{r}$ tabel 0.05

Uji reliabilitas dipakai untuk ketahui keajegan butir soal yang diujikan untuk memberikan hasil pengukuran peningkatan penguasaan kosakata siswa. Untuk menguji 
reliabilitas instrumen peneliti melakukannya melalui SPSS 21.0. Berdasarkan hasil reliabilitas ini dinyatakan lebih besar dari (>) r-tabel yang didapatkan dengan nilai 0,507 > 0,05 maka dikatakan reliabel. Hal ini dapat dilihat pada cronbach's alpha bila nilai $r$ hitung $>r$ tabel, pada $a=5 \%$ dengan $n=20$.

Analisis deskriptif untuk hasil yang didapatkan, maka nilai mean 77,71 , median 86,00 , mode 86 , variance 267,746, minimum 32 , maximum 94.

Uji normalitas dipakai untuk mengetahui jenis statistik yang akan dipakai dalam penelitian tersebut terdistribusi normal/tidak. Uji normalitas data dilakukan dengan rumus one-sample kolmogorov-smirnov dalam perhitungan SPSS-21.0 for windows, kriteria keputusannya adalah bila sig >0,05 maka dinyatakan normal sedangkan jika sig<0,05 dapat dinyatakan tidak normal. Dan disimpulkan bahwa pada uji normalitas hasil post-test peningkatan penguasaan kosakata bahasa Arab berdistribusi normal. Data yang didapatkan kelas eksperimen dengan nilai sig 0,156>0.05 sementara kelas kontrol 0,90>0.05, maka dapat disimpulkan bahwa data hasil pos-test berdistribusi normal.

Setelah diketahui tingkat kenormalan data, selanjutnya dilaksanakan uji homogenitas untuk mengetahui apakah data tersebut mempunyai variansi yang homogen/ tidak. Uji homogenitas dilaksanakan pada nilai post-test kelompok eksperimen dan kelompok kontrol. Berdasarkan hasil diperoleh signifikansi dari hasil post-test peningkatan penguasaan kosakata bahasa Arab siswa/i didapatkan hasil 0,00 maka pada uji homogenitas hasil post-test dinyatakan homogen karena 0,06>0.05, maka dapat disimpulkan bahwa varian kelas eksperimen dan kelas kontrol homogen.

Hipotesis menurut Sugiyono adalah salah satu jawaban yang bersifat sementara pada permasalahan penelitian, sampai terbukti melalui data yang terkumpul (Sugiyono, 2012).

Penelitian bertujuan untuk ketahui teknik flashcard dalam meningkatkan penguasaan kosakata siswa/i kelas VII MTs Al-Muchtari Cimande. Analisis yang digunakan adalah uji-t dengan bantuan SPSS for windows version 21.00. Dari hasil analisis uji-t terhadap 
peningkatan penguasaan kosakata siswa/i dapat diketahui bahwa hasil rata-rata kelas eksperimen 77,71 sedangkan kelas kontrol 1,48 , maka bisa diartikan bahwa Ha diterima karena terdapat peningkatan penguasaan kosakata dengan memakai model belajar bahasa Arab melalui teknik flashcard.

Penelitian ini dilaksanakan di MTs Al-Muchtari Cimande. Adapun sampel penelitian ini adalah kelas VII laki-laki sebagai kelas eksperimen dan kelas VII perempuan sebagai kelas kontrol. Pada kelas eksperimen diberikan sebuah perlakuan dengan menggunakan teknik flashcard, sedangkan kelas kontrol proses pembelajaran seperti biasanya menggunakan buku durusul lughah. Pada setiap pertemuan peneliti lakukan penelitian $4 \mathrm{x}$ pertemuan, setiap pertemuan 2×60 menit, diakhir pertemuan siswa diminta untuk melakukan test dengan soal sebanyak 48 butir.

Teknik flashcard merupakan model belajar yang bisa diterapkan terhadap pembelajaran bahasa Arab untuk tingkatkan penguasaan kosakata bahasa Arab. Proses pembelajaran dengan gunakan teknik flashcard yaitu dengan cara kartu dikocok, serta setiap perwakilan kelompok memiliki kartu flashcard yang telah dibagikan, lalu peneliti memberikan sebuah gambar agar siswa mampu menjawab dengan flashcard yang berada ditangannya. Untuk penilaian flashcard dilakukan ketika siswa mampu menjawab dengan benar, dan permainan ini dilaksanakan dengan cara bergiliran hingga seluruh siswa mempunyai kesempatan untuk bermain.

Hasil nilai post-test menyatakan bahwa terdapat pengaruh penggunaan teknik flashcard untuk penguasaan kosakata siswa MTs Al-Muchtari Cimande dengan rata-rata nilai kelas eksperimen 77,71 dan kelas kontrol 1,48.

Penelitian ini masuk pada penelitian eksperimen. Data penelitian "posttest only control group design" yaitu menempatkan subjek penelitian kedalam dua kelompok (kelas) yang dibedakan jadi kelas eksperimen dan kelas kontrol. Penelitian dilaksanakan di MTs Al-Muchtari Cimande pada tanggal 16-20 Mei 2019. Populasi pada penelitian ini adalah seluruh siswa kelas VII MTs Al-Muchtari Cimande dengan jumlah seluruhnya 31 siswa. Sampel pada penelitian ini adalah siswa laki- 
laki sebagai kelas eksperimen dan siswi perempuan sebagai kelas kontrol.

Sebagaimana peneliti telah mendeskripsikan pada bab sebelumnya bahwa dalam proses teknik pengumpulan data, peneliti gunakan teknik observasi, dokumentasi, dan posttest only.

Teknik observasi bertujuan untuk mengumpulkan data antara lain: mengamati lembaga sekolah, serta proses belajar mengajar bahasa Arab. Dokumentasi digunakan untuk dapatkan data dengan melihat/mengamati atau mencatat langsung proses yang sedang diuji, metode ini dilakukan dengan melihat dokumen seperti gambar, catatan, dan monografi. Selanjutnya posttest adalah latihan tertulis yang dipakai untuk mengukur kognitif dan psikomotorik yang dimiliki siswa .

Di penelitian ini ada dua kelas yaitu kelas eksperimen dan kelas kontrol. Untuk kelas eksperimen diberikan sebuah perlakukan permainan bahasa dengan menggunakan teknik flashcard sedangkan kelas kontrol tidak diberi perlakuan menggunakan teknik flashcard akan tetapi peneliti hanya mengajar seperti pembelajaran biasanya. Serta penelitian ini dilakukan 4 kali pertemuan, dan setiap pertemuan 2x60 menit peneliti mendeskripsikan sebagai berikut:

a. Proses Pelaksanaan Pengajaran Kelas Eksperimen

1) Hari Pertama

Di hari pertama penelitian pada Kamis, 16 Mei 2019 peneliti melakukan sosialisasi akan proses belajar bahasa Arab dengan memakai teknik flashcard, setelah itu para siswa dibagi pada kelompok kecil yaitu 4 orang dalam satu kelompok.

2) Hari Kedua

Pada hari kedua penelitian pada Jum'at, 16 Mei 2019 sebelum menggunakan teknik flashcard, peneliti memberikan pembendaharaan kosakata dengan cara memperlihatkan gambar kepada siswa, kemudian peneliti mengucapkan bahasa Arab kosakata tersebut, diikuti oleh para siswa dan setiap satu kosakata diulang sebanyak 3 kali agar mempermudah siswa untuk mengingat lagi dan menghafalkannya 
3) Hari Ketiga

Pada hari ketiga penelitian pada Sabtu, 18 Mei 2019 peneliti memulai proses pembelajaran bahasa Arab menggunakan teknik flashcard dengan cara setiap perwakilan kelompok maju kedepan untuk melakukan pemainan flashcard untuk mengetahui sejauh mana penguasaan kosakata siswa. Kemudian cara bermain flashcard dengan mengocoknya, serta setiap perwakilan kelompok memiliki kartu flashcard yang telah dibagikan, lalu peneliti memberikan sebuah gambar agar siswa mampu menjawab dengan flashcard yang berada ditangannya. Untuk penilaian flashcard dilakukan ketika siswa mampu menjawab dengan benar, dan permainan ini dilaksanakan dengan cara bergiliran hingga seluruh siswa mempunyai kesempatan untuk bermain.

4) Hari Keempat

Hari terakhir penelitian pada Senin, 20 Mei 2019 peneliti memberikan evaluasi kepada siswa dengan menggunakan instrumen tes, dengan adanya post-test ini peneliti berharap siswa mampu tingkatkan penguasaan kosakata siswa/pelajar.

b. Proses Pelaksanaan Pengajaran Kelas Kontrol

1) Hari Pertama

Di hari pertama penelitian pada Kamis, 16 Mei 2019 peneliti melakukan sosialisasi akan proses pembelajaran bahasa Arab dengan menggunakan kitab durusul lughah dan proses pembelajaran seperti biasanya.

2) Hari Kedua

Hari kedua penelitian pada Jum'at, 17 Mei 2019 peneliti

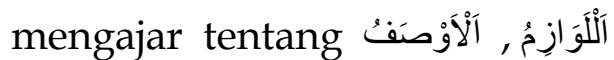
, الَْدَرَسَسَةُ dan dan proses belajar tersebut peneliti memberikan kosakata bahasa Arab satu persatu yang sekaligus diucapkan berulangulang hingga siswa mampu menguasai dan menghafal kosakata tersebut.

3) Hari Ketiga

Hari ketiga penelitian pada Sabtu, 18 Mei 2019 peneliti

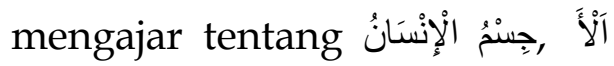


, dُوَانُ dan dalam proses belajaran tersebut peneliti memberikan kosakata bahasa Arab satu persatu yang sekaligus diucapkan berulangulang hingga siswa mampu menguasai dan menghafal kosakata tersebut.

4) Hari Keempat

Hari terakhir penelitian pada Senin, 20 Mei 2019 peneliti memberikan evaluasi kepada siswa dengan menggunakan instrumen tes, dengan adanya post-test ini peneliti berharap siswa mampu tingkatkan penguasaan kosakata siswa/i.

\section{SIMPULAN}

Model pembelajaran yang peneliti gunakan adalah model pembelajaran cooperative-learning dimana siswa belajar dan bekerja dalam kelompok kecil secara kolaboratif yang anggotanya 4 orang dengan struktur kelompok heterogen. Strategi belajarnya khusus untuk dirancang memberi dorongan kepada peserta didik agar kerjasama selama proses pembelajaran. Cooperative learning ini dapat meningkatkan sikap tolong menolong dalam perilaku sosial. Siswa di beri motivasi untuk berani mengemukakan pendapat, menghargai pendapat teman dan saling tukar pendapat.

Berdasarkan hasil pembahasan analisis data penelitian maka disimpulkan terdapat pengaruh terhadap peningkatan penguasaan kosakata bahasa Arab dengan menggunakan teknik flashcard. Hasil dari perhitungan one sample $t$-test data dengan rata-rata menyatakan bahwa terdapat pengaruh penggunaan teknik flashcard untuk penguasaan kosakata siswa MTS Al-Muchtari Cimande dengan rata-rata nilai kelas eksperimen 77,71 dan kelas kontrol 1,48. Uji normalitas data yang didapatkan kelas eksperimen dengan nilai sig 0,156>0.05 sementara kelas kontrol 0,90>0.05, Serta untuk uji homogenitas signifikansi dari hasil post-test peningkatan penguasaan kosakata bahasa Arab siswa didapatkan hasil 0,00 maka pada uji homogenitas hasil post-test dinyatakan homogen karena 0,06>0.05, maka dapat disimpukan bahwa varian kelas eksperimen dan kelas kontrol homogen.maka dapat disimpulkan bahwa data hasil pos-test berdistribusi normal. 
DAFTAR PUSTAKA

Arsyad, A. (2016). Media Pembelajaran. PT.Raja Gravindo Persada.

Hartati, N. (2017). Statistika untuk Analisis Data Penelitian. Pustaka Setia.

Matsna, M. (2014). Evaluasi Pembelajaran Bahasa Arab. UIN PRESS.
Nuha, U. (2012). Metodologi Super Efektif Pembelajaran Bahasa Arab. Diva Press.

Sugiyono. (2012). Metode Penelitian Kuantitatif Kualitatif dan RED. Alfabeta.

Sugiyono. (2015). Metode Penelitian. Metode Penelitian.

Wekke, I. S. (2016). Pembelajaran Bahasa Arab di Madrasah. CV.Budi Utama. 